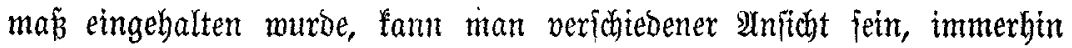
find bie vorliegendent Elemente zu Den befieren Sompenbien über ßotanif zu rectinen.

\title{
IV. Altutizen.
}

\section{Zeue Waldverderber.}

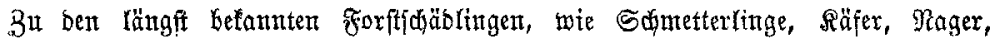

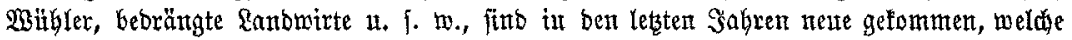

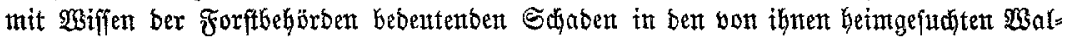
Dungen anriditert.

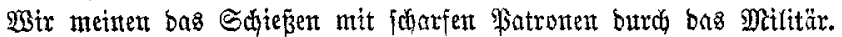

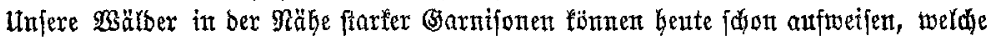

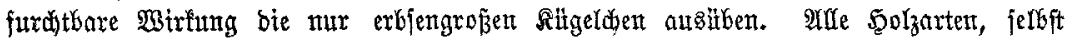

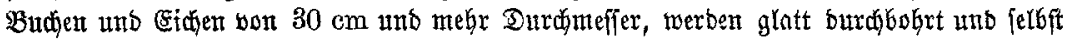

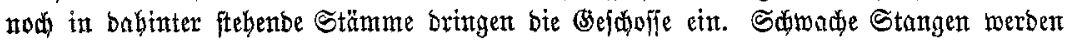

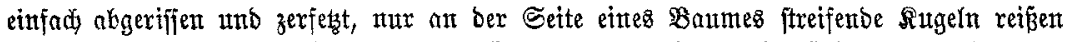

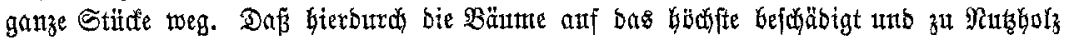

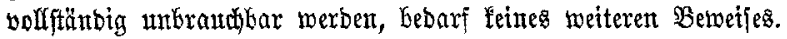

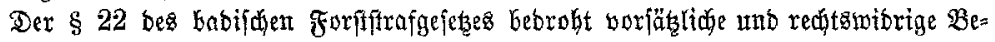

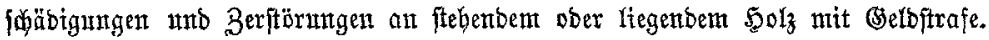

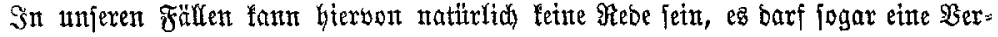

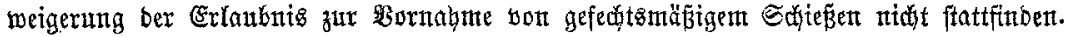

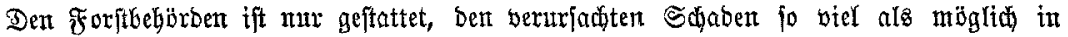

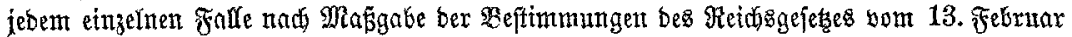

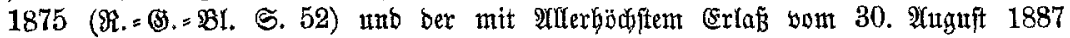

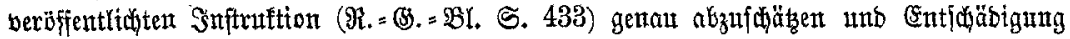
zat verlanger.

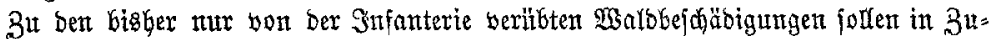

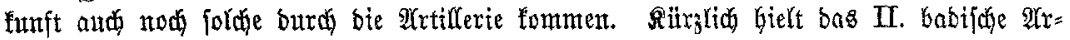

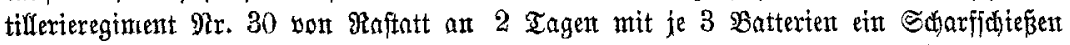

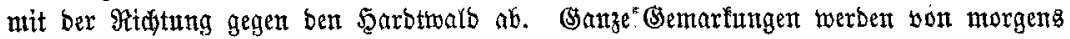

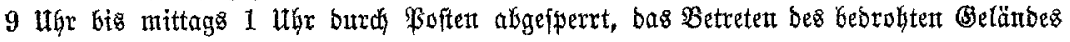
ift frrengftents berboten.

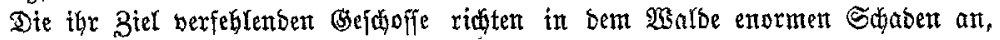

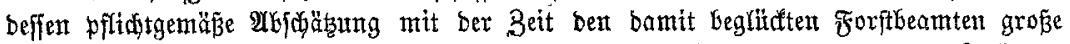

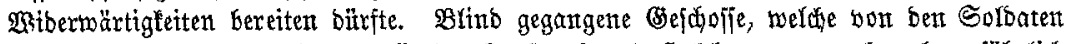

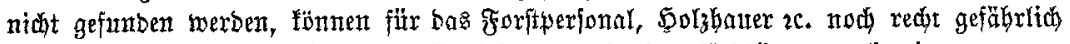

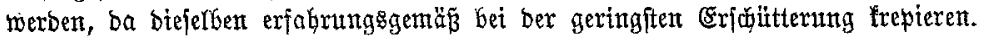

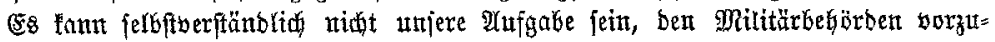

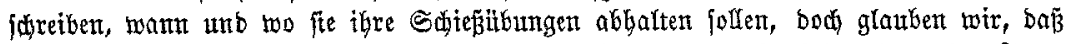
es angezeigt fei, im \$ntereffe unjerer bebrobten Balbuntgen bie Befprectung ber Frage in urieren Fratzeitfouriften anzuregett.

Æ.

$\mathfrak{B}$., DGerförp̈ter. 